University of Nebraska - Lincoln

DigitalCommons@University of Nebraska - Lincoln

Utility of Lipid Biomarkers in Support of Bioremediation Efforts at Army Sites

D. Ringelberg

U.S. Army ERDC-CRREL, 72 Lyme Rd., Hanover, NH 03755, United States

M. Richmond

U.S. Army ERDC-CRREL, 72 Lyme Rd., Hanover, NH 03755, United States

K. Foley

U.S. Army ERDC-CRREL, 72 Lyme Rd., Hanover, NH 03755, United States

C. Reynolds

U.S. Army ERDC-CRREL, 72 Lyme Rd., Hanover, NH 03755, United States

Follow this and additional works at: https://digitalcommons.unl.edu/usarmyresearch

Part of the Operations Research, Systems Engineering and Industrial Engineering Commons

Ringelberg, D.; Richmond, M.; Foley, K.; and Reynolds, C., "Utility of Lipid Biomarkers in Support of Bioremediation Efforts at Army Sites" (2008). US Army Research. 51.

https://digitalcommons.unl.edu/usarmyresearch/51

This Article is brought to you for free and open access by the U.S. Department of Defense at DigitalCommons@University of Nebraska - Lincoln. It has been accepted for inclusion in US Army Research by an authorized administrator of DigitalCommons@University of Nebraska - Lincoln. 


\title{
Utility of lipid biomarkers in support of bioremediation efforts at army sites
}

\author{
D. Ringelberg *, M. Richmond, K. Foley, C. Reynolds \\ U.S. Army ERDC-CRREL, 72 Lyme Rd., Hanover, NH 03755, United States
}

Received 25 June 2007; received in revised form 16 July 2007; accepted 16 July 2007

Available online 21 July 2007

\begin{abstract}
Lipid biomarker analysis has proven valuable in testing the hypothesis that attributes of the extant microbiota can directly reflect the occurrence of contaminant biodegradation. Two past research efforts have demonstrated this utility and are described here.

A $4.5 \mathrm{~m}$ vertical core was obtained from a diesel fuel oil contamination plume. Core material was assayed for total petroleum hydrocarbons (TPH) and bacterial membrane phospholipids (PLFA) via a single solvent extraction. Microbial viable biomass and the relative abundance of Gram-negative bacterial PLFA biomarkers were found to be significantly correlated with TPH concentration. The core TPH profile also revealed two distinct areas where the average TPH level of $3000 \mu \mathrm{g} \mathrm{g}^{-1}$ fell to near detection limits. Both areas were characterized by a three-fold decrease in the hexadecane/pristane ratio, indicating alkane biodegradation, and a distinct PLFA profile that showed a close similarity to the uncontaminated surface soil.

Low-order, incomplete detonations can deposit hexahydro-1,3,5-trinitro-1,3,5-triazine (RDX) into training range surface soils. Since surface soils are exposed to temporal and diurnal moisture cycles, we investigated the effect two very different soil moisture tensions had on the in situ microbiota and RDX biodegradation. Saturated soils were characterized by rapid RDX biodegradation, 4 day half-life, a decrease in number of

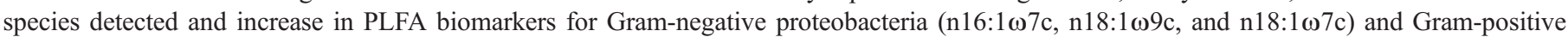
firmicutes (i15:0 and a15:0). Terminal restriction fragment length polymorphism (T-RFLP) profiles of endpoint microbial communities indicated a shift from 18 to $36 \%$ firmicutes, the loss of gamma-proteobacteria and the emergence of alpha-proteobacteria.

These two past research efforts demonstrated the utility of the lipid biomarker analysis in identifying microbial community characteristics that were associated with two very different soil contaminants. Lipid biomarkers defined areas of TPH biodegradation and identified community shifts as a result of soil conditions that affected explosives fate. Information like this can be used to enhance the predictive power of ecological models such as the Army Training and Testing Area Carrying Capacity for munitions model [ATTACC].
\end{abstract}

Published by Elsevier B.V.

Keywords: Lipid biomarkers; PLFA; TPH; RDX; Contaminated soil

\section{Introduction}

"The microbial community contains a record of the sum microbial response to the environment, which is written from changes in the biochemistry of the extant organisms" (David C. White).

Contaminant effects on the in-situ microbiota are generally continuous and the changes induced in community structure and activity can become integrated over long periods of time (Smith

\footnotetext{
* Corresponding author. Tel.: +1 6036464744 .

E-mail address: David.B.Ringelberg@erdc.usace.army.mil (D. Ringelberg).
}

et al., 1986). For example, a contaminant can trigger the loss or emergence of a particular genera or species of microorganism or trigger a specific catabolic capacity within a single species (Ringelberg et al., 2001). Consequently, it is hypothesized that the in-situ microbiota contains a signature of past and present contaminant exposure and utilization. A comprehensive measure of the in-situ microbial ecology of a site will yield the identity of such a signature.

Currently, there is no universally accepted protocol for monitoring site microbial ecology. Culture and isolation techniques can provide valuable information regarding organism presence and potential activity, but it is now known that organisms in culture poorly reflect in-situ diversity and activity levels (American Academy of Microbiology, 2002). Molecular 
based assays are now recognized as a non-biased and accurate means of determining in-situ microbial community structure, diversity and activity. With a combination of molecular assays, it is now possible to obtain a comprehensive and quantitative definition of the in-situ microbial ecology of a site.

Here, we report findings from two studies where the in-situ microbiology surrounding total petroleum hydrocarbons (TPH) and hexahydro-1,3,5-trinitro-1,3,5-triazine (RDX) biodegradation was described using "whole-sample" characterization techniques or the direct assay of microbes in situ. The area selected for the TPH investigation was used as a fuel dispensing facility from late 1940 through early 1990 . The subsurface had a mean hydraulic conductivity of $1.98 \times 10^{-2} \mathrm{~cm} / \mathrm{s}$ and this level of permeability raised concern over the transport of the contamination plume into underlying groundwater (approximately $5 \mathrm{~m}$ below the surface). Since nearby drinking water supplies were in close proximity, environmental health issues were paramount and, as a result, remedial actions were initiated. As part of the remedial actions, this study focused on examining the subsurface microbial ecology and the relationships that existed between the extant microbiota and the contamination. The intent of the study was to identify community attributes that were associated with the in situ biodegradation of the petroleum hydrocarbons.

In the other study, we monitored shifts in microbial community composition resulting from two different soil water potentials in the presence of added RDX. Our previous work had demonstrated that RDX biodegradation proceeded at a rate seven times faster under water saturated versus an unsaturated condition. Here we show that the increase in the rate of RDX biodegradation coincided with a big shift in microbial community composition. The working hypothesis is that soil moisture content imparts a major influence on soil microbial community composition that, in turn, can directly or indirectly affect RDX biodegradation. PLFA and TRFLP analyses were used to identify the nature of the community shift.

"A definition of natural attenuation in terms of a site's microbial ecology is defensible, whereas a definition in terms of contaminant chemistry and/or site geochemistry or hydrology is only circumstantial" (David C. White).

\section{Materials and methods}

\subsection{TPH Study}

\subsubsection{Sample material}

For the TPH study, subsurface material was collected from Fort Drum, NY, USA in three $5 \mathrm{ft} \times 3$ in. ID split-barrel samplers fitted with a butyrate liner and driven with a $140 \mathrm{lb}$ hammer dropped from 30 in (Talley et al., 2004). Sample material was mostly homogenous and comprised primarily of medium sands with some fines. All sampling materials were steam sterilized prior to use. Recovered cores were labeled, capped, sealed in wax and transported to laboratory at $5{ }^{\circ} \mathrm{C}$ in a refrigerated truck. One gram samples of material were collected over the entire length of the core.

\subsubsection{Analyses}

Sample total petroleum hydrocarbons (TPH) and PLFA were co-recovered by extracting $1 \mathrm{~g}$ of material in $3.5 \mathrm{ml}$ of methylene chloride, methanol and aqueous phosphate buffer. The soil solvent mixture was subjected to 2 min. of sonication and extracted for a period of $3 \mathrm{~h}$. at room temperature. Additional aliquots of methylene chloride and water $(1 \mathrm{ml}$ each) were then added to the mixture, shaken vigorously, and allowed to separate overnight. The organic phase was recovered and passed through a silica gel column $(0.5 \mathrm{~g})$. The column was eluted sequentially with $5 \mathrm{ml}$ methylene chloride, $5 \mathrm{ml}$ acetone and $5 \mathrm{ml}$ methanol, collecting each eluent.

One $\mu l$ of the methylene chloride eluent was injected on a HP5890 gas chromatograph equipped with a SPB-5 capillary column (60 m, .32 mm ID, $.25 \mu \mathrm{m}$ film) programmed from $50{ }^{\circ} \mathrm{C}(2 \mathrm{~min})$ to $310{ }^{\circ} \mathrm{C}(3 \mathrm{~min})$ at $4{ }^{\circ} \mathrm{C} / \mathrm{min}$ for total $\mathrm{TPH}$ quantification. A splitless injection of $1 \mathrm{~min}$ was used at a purge of $80 \mathrm{ml} / \mathrm{min}$. The injector was maintained at $250{ }^{\circ} \mathrm{C}$ and the flame ionization detector at $320{ }^{\circ} \mathrm{C}$. Equal response was assumed for all peaks eluting between the retention times of 10 and $50 \mathrm{~min}$. An internal standard calculation was applied to peak areas with nonadecanoic acid methyl ester at 50 pmole $\mu \mathrm{l}^{-1}$ serving as the internal standard.

PLFA were then recovered from the methanol eluent as described in White and Ringelberg (1998). PLFA were first trans-esterified in mild-alkaline methanol to obtain fatty acid methyl esters and then separated and quantified via capillary gas chromatography - mass spectrometry. Mass spectra were collected at $70 \mathrm{eV}$ using positive electron impact ionization. An internal standard calculation was applied to peak areas with nonadecanoic acid methyl ester at 50 pmole $\mu 1^{-1}$ serving as the internal standard. Each PLFA profile represented a fingerprint of the extant microbial community with the sum total of all detected PLFA representing the total in situ viable microbial biomass (Balkwill et al., 1988).

\subsection{RDX study}

\subsubsection{Sample material}

For the RDX study, surface soil was collected by hand from Ft. Greely, Alaska and shipped to the laboratory at ambient temperature. The material was sieved $(4 \mathrm{~mm})$ and air dried for storage. Dry soils ( $5 \mathrm{~g}$ each) were pre-incubated in $40-\mathrm{mL}$ vials in $1 \mathrm{ml} \mathrm{H}_{2} \mathrm{O}$ (Milli-Q grade) at room temperature $\left(21^{\circ} \mathrm{C} \pm 2{ }^{\circ} \mathrm{C}\right.$ ) for $48 \mathrm{~h}$ to acclimate the system prior to RDX addition. Individual microcosms were then augmented with 2 or $25 \mathrm{ml}$ aqueous RDX to a final concentration of $10 \mathrm{mg} \mathrm{RDX} \mathrm{L}^{-1}$ (unsaturated and saturated, respectively). Control microcosms were established by autoclaving $\left(120{ }^{\circ} \mathrm{C}\right.$ for $\left.20 \mathrm{~min}\right)$ replicate microcosms three consecutive times, with an 8 -hour resting period between sterilizations. The saturated microcosms also received $100 \mu \mathrm{L}$ of a $0.1 \%$ resazurin solution as a redox indicator. Following the RDX addition, microcosms were incubated for a total of $840 \mathrm{~h}$ in the dark without agitation at room temperature $\left(21{ }^{\circ} \mathrm{C} \pm 2{ }^{\circ} \mathrm{C}\right)$. Three replicate vials were sacrificed at $0,48,168,504$, and $840 \mathrm{~h}$ to obtain microbiological and contaminant chemistry data. 


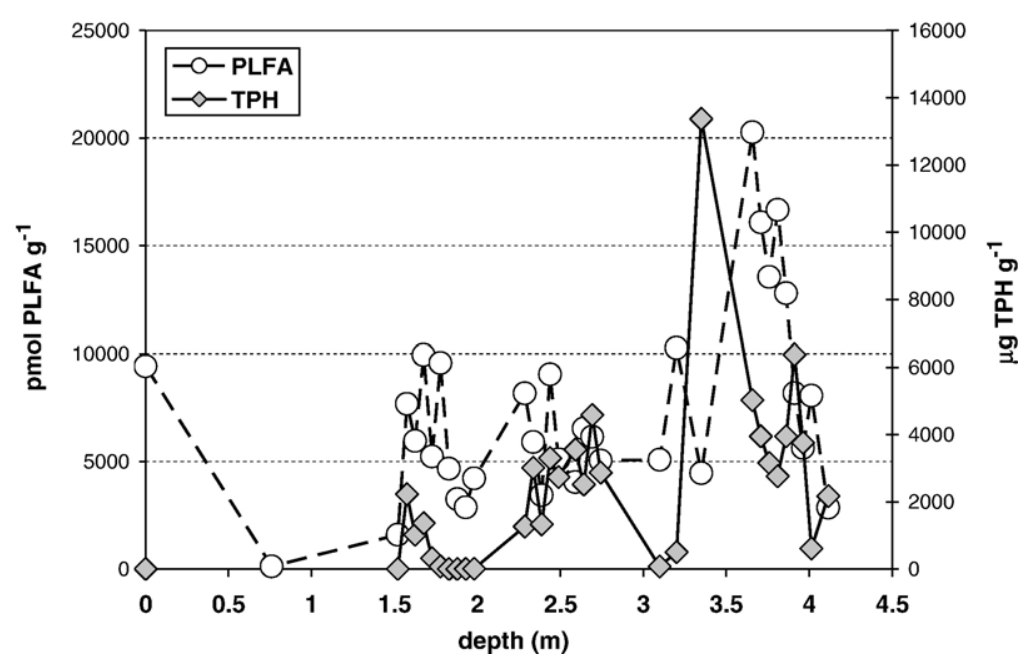

Fig. 1. TPH concentration and PLFA abundance are plotted against depth for the Fort Drum subsurface core materials. Microbial biomass (PLFA) correlated with the hydrocarbon (TPH) contamination.

\subsubsection{Analyses}

Total extractable RDX was recovered as described in Ringelberg et al. (2003). Briefly, solids were extracted in $10 \mathrm{ml}$ acetonitrile $(\mathrm{ACN})$ with sonication for $18 \mathrm{~h}$ at $20^{\circ} \mathrm{C}$. Liquids were assayed directly following centrifugation. ACN extracts were diluted with water and water extracts diluted with $\mathrm{ACN}$, then both were filtered $(0.45 \mu \mathrm{m}$ Milipore Millex-FH, Bedford, MA) prior to analysis by HPLC. RDX was quantified on a $15-\mathrm{cm}$ by $3.9-\mathrm{cm}(4-\mu \mathrm{m})$ Nova Pak C8 (Waters Millipore) column by elution in $1.5 \mathrm{ml} \mathrm{min}{ }^{-1}$ of $15: 85$ isopropanol: $\mathrm{H}_{2} \mathrm{O}$ (v:v). Absorbance at $254 \mathrm{~nm}$ was recorded.
Microbial populations were fingerprinted via PLFA and by the terminal restriction fragment length polymorphism (T-RFLP) assay (Gruntzig et al., 2002). For PLFA, approximately $2 \mathrm{~g}$ of microcosm solids were extracted in $7.6 \mathrm{ml}$ of chlorofrom:methanol:phosphate buffer $(1: 2: 0.8, \quad \mathrm{v}: \mathrm{v}: \mathrm{v})$ and processed as described in White and Ringelberg (1998).

For the T-RFLP assay, approximately $1 \mathrm{~g}$ of microcosm solid was extracted for total genomic DNA using the MoBio UltraClean DNA isolation kit (MoBio Laboratories, Carlsbad, CA). A portion of the $16 \mathrm{~S}$ gene was then amplified via PCR using primers $8 \mathrm{~F}$ and $926 \mathrm{R}$. Following purification, the amplicon was
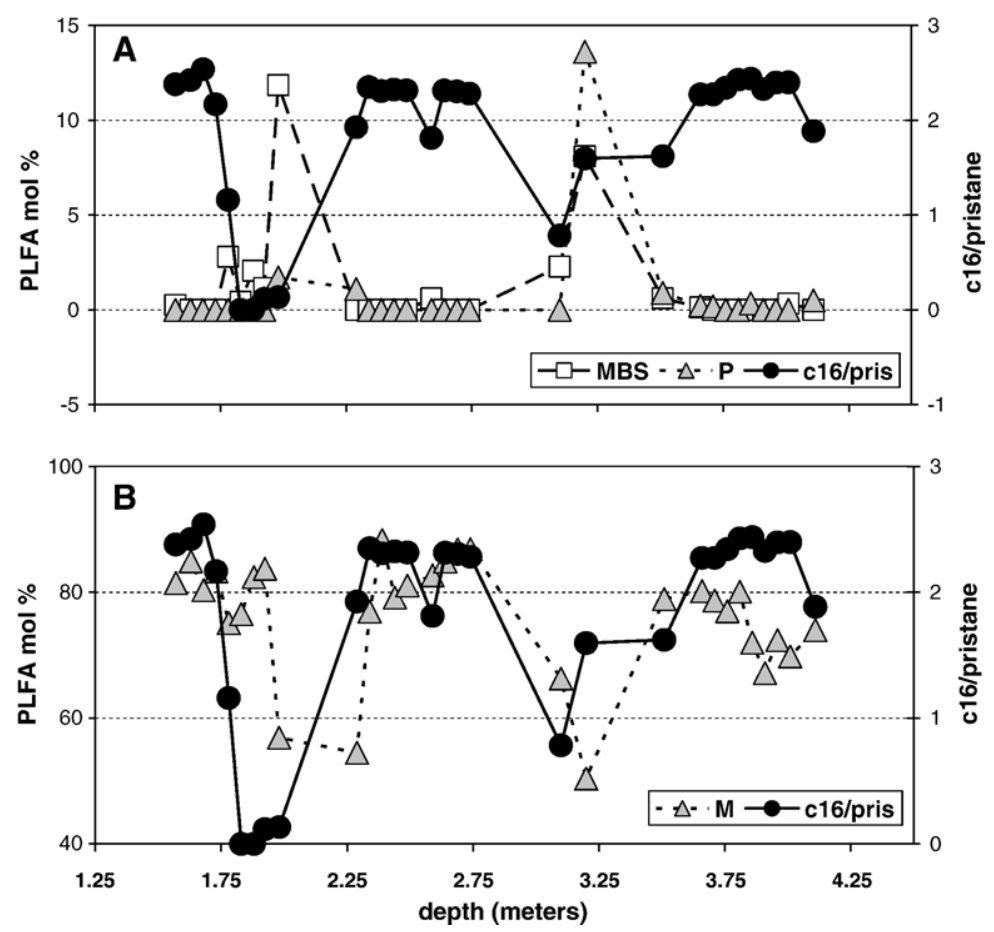

Fig. 2. The TPH biodegradation ratio, hexadecane (C16) to pristane, is plotted against depth for the Fort Drum subsurface core materials. Co-plotted in panel A are the mole percentages of PLFA biomarkers for actinomycetes, mid-chain methyl branched saturates (MBS) and for micro-eukaryotes, polyunsaturates (P), and in panel B the PLFA biomarkers for Gram-negative bacteria, monounsaturates (MONO). 
digested using the Hha I, Msp I and Rsa I endonucleases (20 U each at $37{ }^{\circ} \mathrm{C}$ for $3 \mathrm{~h}$.). The digested fragments were then separated and sized via capillary electrophoresis. Fragment sizes were compared to those contained in the RDP-II database (Ribosomal Database Project, Michigan State University) using the FragSorter program (Ohio State University). The goal was to taxonomically assign the individual fragments (and associated abundance).

\section{Results and discussion}

\subsection{In situ characterization of TPH biodegradation}

\subsubsection{Contaminant chemistry}

TPH concentration vs. depth is plotted for each point sampled along the continuous core (Fig. 1). The highest TPH concentration, $13,000 \mu \mathrm{g} \mathrm{g}^{-1}$, was detected at a depth of $3 \mathrm{~m}$. One gram of soil was found to contain sufficient amounts of contaminant and microbial cells for analysis. TPH recovery by the method described above was found comparable to EPA methods 3550 and 8015 . In addition, A few $10 \mathrm{~g}$ core samples were extracted to assure that the $1 \mathrm{~g}$ extractions were not influenced by spatial heterogeneity. Results from the 1 and $10 \mathrm{~g}$ extractions were within 1 standard deviation of each other.

Work coming out of the Exxon Valdez oil spill in Prudhoe Bay, Alaska indicated that chemical signatures could be used to identify the occurrence of microbial biodegradation of crude oil (Prichard and Cosca, 1991). Other researchers have also found that a decrease in the ratio of n-alkanes over branched acyclic isoprenoids coincides with biodegradation activity (McIntyre et al., 2007). Two areas along the continuous core showed decreases in the ratio of hexadecane to pristane, 1.7 to $2.2 \mathrm{~m}$ and

Table 1

Contaminant chemistry, microbial biomass, community composition and K-means assignments from Fort Drum subsurface core material taken at each depth sampled

\begin{tabular}{|c|c|c|c|c|c|c|c|c|c|c|c|}
\hline \multirow{3}{*}{$\begin{array}{l}\text { Depth } \\
(\mathrm{m})\end{array}$} & \multicolumn{2}{|c|}{ Contaminant chemistry } & \multirow{3}{*}{$\frac{\text { Microbial biomass }}{\left.\text { PLFA (pmole } \mathrm{g}^{-1}\right)}$} & \multicolumn{5}{|c|}{ Microbial community composition } & \multirow{2}{*}{\multicolumn{3}{|c|}{$\frac{\text { K-means association }{ }^{\mathrm{a}}}{(\text { Group \#) }}$}} \\
\hline & \multirow{2}{*}{$\begin{array}{l}\text { ТРH } \\
\left(\mu \mathrm{g} \mathrm{g}^{-1}\right)\end{array}$} & \multirow{2}{*}{$\begin{array}{l}\text { Hexadecane/ } \\
\text { pristane }\end{array}$} & & Trans/cis ${ }^{\mathrm{b}}$ & $\mathrm{TBS}^{\mathrm{c}}$ & $\mathrm{MONO}^{\mathrm{d}}$ & $\mathrm{MBS}^{\mathrm{e}}$ & POLY ${ }^{\mathrm{f}}$ & & & \\
\hline & & & & \multicolumn{5}{|c|}{ (Mole percentage) } & $\# 1$ & $\# 2$ & $\# 3$ \\
\hline 0.76 & 0 & - & 128 & 0.00 & 3.1 & 39.5 & 3.2 & 13.6 & & & $\mathrm{X}$ \\
\hline 1.52 & 3 & - & 1597 & 0.00 & 18.2 & 55.0 & 6.1 & 2.0 & & & $\mathrm{X}$ \\
\hline 1.57 & 2229 & 2.4 & 7676 & 0.24 & 9.1 & 81.5 & 0.3 & 0.0 & & $\mathrm{X}$ & \\
\hline 1.73 & 326 & 2.2 & 5233 & 0.19 & 8.4 & 83.3 & 0.0 & 0.0 & & $\mathrm{X}$ & \\
\hline 1.78 & 79 & 1.2 & 9575 & 0.09 & 13.4 & 75.1 & 2.8 & 0.0 & & & $\mathrm{X}$ \\
\hline 1.83 & 1 & 0.0 & 4662 & 0.05 & 15.0 & 76.5 & 0.4 & 0.0 & & & $\mathrm{X}$ \\
\hline 1.88 & 1 & - & 3254 & 0.04 & 7.7 & 82.4 & 2.1 & 0.0 & & & $X$ \\
\hline 1.93 & 7 & 0.1 & 2872 & 0.23 & 6.1 & 83.7 & 1.1 & 0.0 & & & $X$ \\
\hline 1.98 & 13 & 0.1 & 4213 & 0.09 & 9.2 & 56.9 & 11.9 & 1.7 & & & $\mathrm{X}$ \\
\hline 2.49 & 2738 & 2.3 & 5098 & 0.23 & 8.1 & 81.1 & 0.0 & 0.0 & & $\mathrm{X}$ & \\
\hline 2.59 & 3556 & 1.8 & 4039 & 0.33 & 6.3 & 82.7 & 0.6 & 0.0 & & $\mathrm{X}$ & \\
\hline 2.64 & 2520 & 2.3 & 6530 & 0.28 & 5.3 & 84.9 & 0.0 & 0.0 & & $\mathrm{X}$ & \\
\hline 2.69 & 4584 & 2.3 & 6148 & 0.32 & 4.0 & 86.8 & 0.0 & 0.0 & & $\mathrm{X}$ & \\
\hline 2.74 & 2868 & 2.3 & 5040 & 0.36 & 4.1 & 86.8 & 0.0 & 0.0 & & $\mathrm{X}$ & \\
\hline 3.10 & 76 & 0.8 & 5083 & 0.11 & 14.1 & 66.3 & 2.3 & 0.0 & & & $\mathrm{X}$ \\
\hline 3.20 & 507 & 1.6 & 10,259 & 0.13 & 8.1 & 50.4 & 8.1 & 13.6 & & & $\mathrm{X}$ \\
\hline 3.35 & 13,369 & 1.6 & 4457 & 0.26 & 4.2 & 78.9 & 0.6 & 0.9 & $\mathrm{X}$ & & \\
\hline 3.66 & 5022 & 2.3 & 20,272 & 0.31 & 4.1 & 80.1 & 0.1 & 0.2 & $X$ & & \\
\hline 3.71 & 3947 & 2.3 & 16,087 & 0.22 & 4.6 & 78.7 & 0.0 & 0.2 & $\mathrm{X}$ & & \\
\hline 3.76 & 3155 & 2.3 & 13,547 & 0.15 & 2.1 & 77.0 & 0.0 & 0.0 & $X$ & & \\
\hline 3.81 & 2762 & 2.4 & 16,670 & 0.16 & 1.2 & 80.1 & 0.0 & 0.0 & $\mathrm{X}$ & & \\
\hline 3.86 & 3950 & 2.4 & 12,792 & 0.16 & 2.9 & 72.0 & 0.0 & 0.3 & $X$ & & \\
\hline
\end{tabular}

${ }^{\mathrm{a}}$ K-means cluster groups from arcsin transformed PLFA mole percentages, whole profiles.

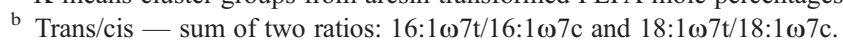

c Sum of all terminally branched saturated PLFA.

${ }^{\mathrm{d}}$ Sum of all monounsaturated PLFA.

e Sum of all mid-chain methyl branched saturated PLFA.

${ }^{\mathrm{f}}$ Sum of all polyunsaturated PLFA. 
2.7 to $3.5 \mathrm{~m}$ (Fig. 2). These two areas were identified as zones where in situ biodegradation of petroleum hydrocarbons had occurred or was an active process at the time of sampling. Both proposed biodegradation zones were bordered on either side by samples containing 500-5000 $\mu \mathrm{g} \mathrm{g}^{-1} \mathrm{TPH}$.

\subsubsection{Microbial community analysis}

The intent of this study was to identify community attributes that were associated with the in situ biodegradation of the petroleum hydrocarbons. Microbial biomass (pmole PLFA $\mathrm{g}^{-1}$ soil) was found to run parallel to contaminant concentrations and a significant positive correlation, Spearman $r=0.56$, $p=.0005$, was identified between the two measures (Fig. 1). A conversion of the PLFA values to cell numbers, assuming that 1 pmole PLFA is equivalent to $2.5 \times 10^{4}$ bacterial cells (Balkwill et al., 1988), indicated the surface soil to contain approximately $4 \times 10^{8}$ cells $\mathrm{g}^{-1}$. This biomass level dropped by an order of magnitude by the $0.8 \mathrm{~m}$ depth, which is a typical phenomenon for microbial distribution in soils (for example - Federle et al., 1986). However, microbial biomass rebounded to greater than surface cell numbers between $1.5 \mathrm{~m}$ and $4.5 \mathrm{~m}$ (Fig. 1). The relationship between biomass and TPH concentration suggests that a significant interaction existed between the indigenous microbiota and the contamination. Margesin et al. (2007) came to a similar conclusion in the evaluation of a different diesel-oil contaminated soil.

Specific microbial PLFA biomarkers were then examined in relationship to the alkane/acyclic isoprenoid ratio (Fig. 2). Two structural classes of PLFA, the mid-chain branched saturates and the polyunsaturates, showed an inverse relationship to the hexadecane/pristane ratio (Fig. 2A). Mid-chain branched saturates, in particular the 10-methyl branched moieties, are indicative of a number of actinomycetes whereas the polyunsaturates are indicative of micro-eukaryotes (Lechevalier and Lechevalier, 1988; Pinkart et al., 2002). Species of both fungi and actinomycetes have been shown to degrade petroleum hydrocarbons (Mancera-Lopez et al., 2007; Baek et al., 2004). However, another possibility, put forth by Margesin et al. (2003), is that, although present, the fungi and actinomycetes may not have been actively involved in the TPH biodegradation. A number of researchers have seen the enrichment of Gram-negative bacteria as a result of TPH contamination (see Balba et al., 1998 for a brief review). Being r-strategist organisms, certain Gram-negative bacteria proliferate when an excess of added carbon, in this case $\mathrm{TPH}$, is present. $\mathrm{K}$ strategists, such as Gram-positive bacteria, actinomycetes, and fungi that are likely present in the soil prior to the contamination event, are more efficient organisms and therefore more successful in resource limited situations. The biodegradation of petroleum hydrocarbons by r-strategists could have allowed the $\mathrm{k}$-strategists to resume their natural position within the soil community. In this study, we also observed a high percentage of Gram-negative bacterial PLFA biomarkers in association with high TPH concentrations (Table 1 and Fig. 2B). Monounsaturated PLFA are indicative of Gram-negative bacteria and were by far the most prominent PLFA detected in these samples.

Exploratory statistics were then used to determine if a whole community attribute could be related to the observed changes in

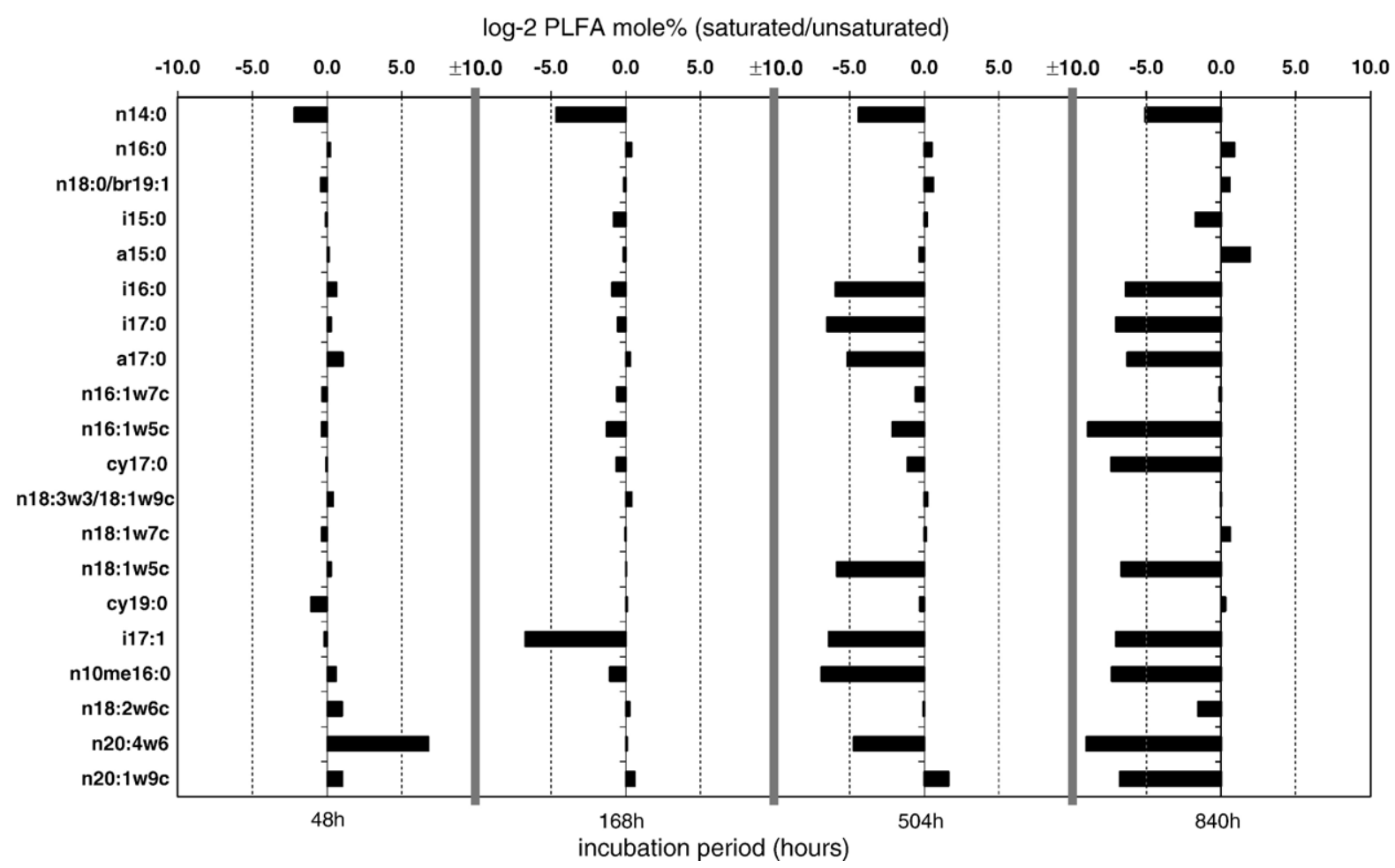

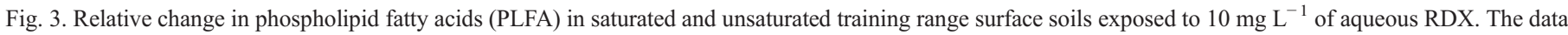

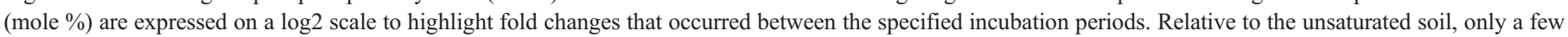
PLFA were enriched in the saturated soil. 
TPH chemistry. By application of a K-means hierarchical cluster analyses, three community profiles of the greatest possible distinction were defined (Table 1). Community 3, characterized by significantly greater mole percentages of terminally and mid-chain branched saturated and polyunsaturated PLFA, was identified in samples exhibiting low TPH concentrations and a decreased hexadecane/pristine ratio. Community 3 samples included the surface and two near surface samples. Our interpretation is that this community represented a community of $\mathrm{K}$-strategist microorganisms that persisted through the past TPH exposure and subsequent remediation. This is opposed to a community of actively biodegrading microorganisms, such as community 2 , which is characterized by a high monounsaturated mole percentage and increased trans/cis ratio. These findings, monounsaturated \% and high trans/cis ratios, are very similar to those observed by MacNaughton et al. (1999) when examining the microbiology

\section{un-saturated Phyla}

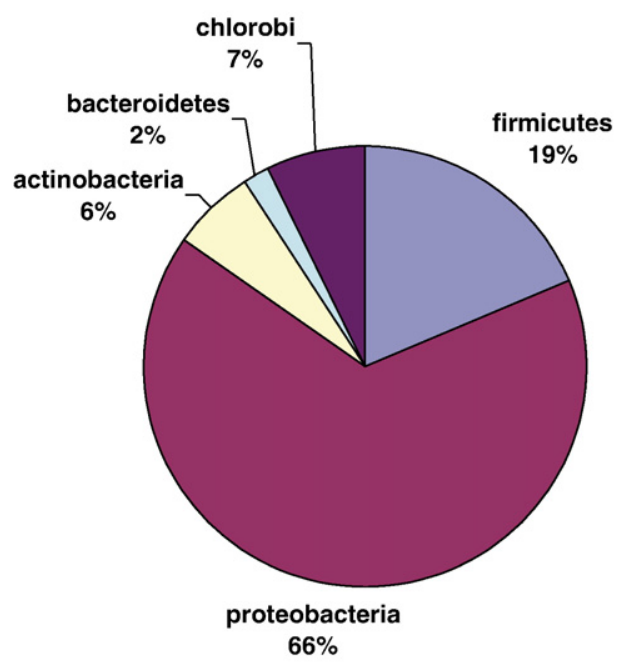

saturated Phyla



surrounding crude oil biodegradation. The trans/cis ratio has been used as a descriptor of the physiological health of Gramnegative bacterial communities, with ratios less than 0.05 indicating a healthy community (White et al., 1998). The high trans/cis ratios observed here likely reflect the exposure of the Gram-negative populations to high TPH concentrations in a similar manner as when Gram-negative bacteria are exposed to solvents (Sikkema et al., 1995).

In summary, by examining the in situ microbial PLFA signatures, we were able to relate specific community attributes to a chemical measure of TPH biodegradation. TPH biodegradation could be characterized by either a whole community fingerprint (i.e. community 2) or by an individual PLFA attribute (i.e. tran/cis ratio). In addition, the successful attenuation of the diesel fuel spill could also be monitored. The identified community fingerprint, i.e. community 3 , and individual PLFA attributes, i.e. actinomycete and micro-eukaryote

\section{un-saturated Proteobacteria}

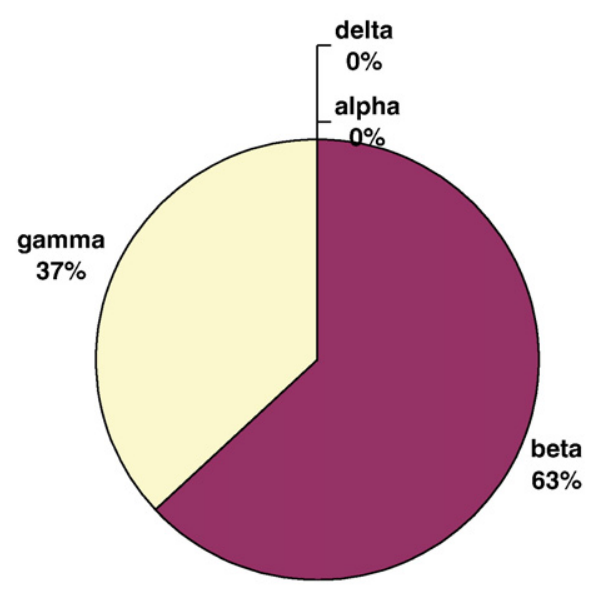

saturated proteobacteria

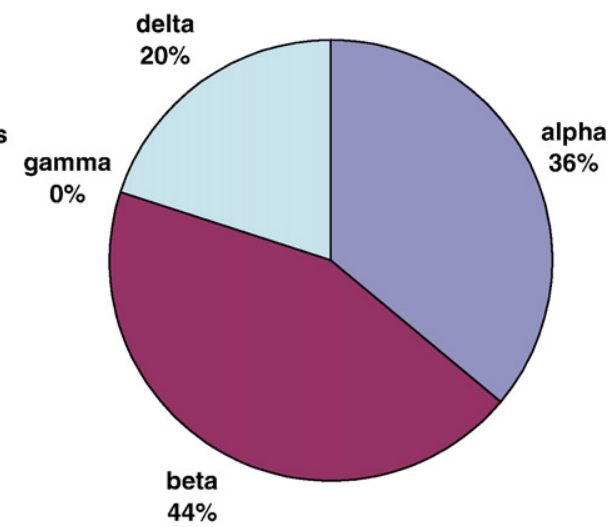

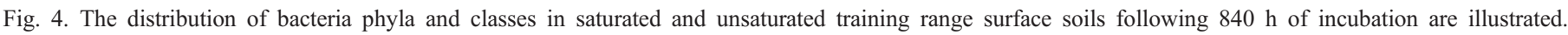

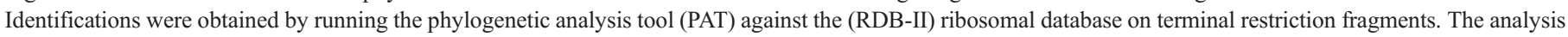
revealed an increase in the proportion of firmicutes and the emergence of alpha- and delta-proteobacteria in the saturated soil. 
percentages, represented benchmarks or endpoints for identifying the successful bioremediation of the TPH contamination.

\section{2. $R D X$ biodegradation}

The soil used in this study had a demonstrated capacity for the biological transformation of RDX (Ringelberg et al., 2003). Halflives for the added RDX were 4 days saturated and 29 days unsaturated. These values were similar to those reported by Zhao et al. (2004) for aqueous RDX in marine sediment $\left(\right.$ at $10^{\circ} \mathrm{C}$ ) and Speitel et al. (2001) for RDX in a soil at a gravimetric moisture level of $8 \%$. A number of reports have also shown that reduced conditions can be ideal for RDX biodegradation (McCormick et al., 1981; Boopathy et al., 1998; Guiot et al., 1999; Speitel et al., 2001). Since saturated soils can rapidly become anoxic, given sufficient biomass and bio-available carbon, soil moisture likely plays a pivotal role in RDX biodegradation.

The soils contained $\sim 10^{8}$ cells $\mathrm{g}^{-1}$ at the time RDX was added in aqueous form, which is a typical cell density for a surface soil. A plot of saturated to un-saturated PLFA (on a $\log 2$ scale to enhance fold changes) showed a dramatic shift to occur in the saturated PLFA profile over the time course of the study (Fig. 3). Relative to the un-saturated soil, very few PLFA became enriched under the saturated condition. Instead there was a significant drop in the number of PLFA detected. The loss in PLFA diversity was also associated with a loss in total PLFA abundance, approximately $1 / 3$ that of the un-saturated soil. The decreased biomass and fewer number of detectable PLFA was likely an indication of increased selective pressures on microbial growth, e.g. $\mathrm{O}_{2}$ availability, as indicated by a color change in the added resazurin dye.

To further resolve the in situ descriptions of microbial community composition and to specifically address species numbers, the T-RFLP assay was applied. The number of bacterial species identified in the saturated soils was approximately $60 \%$ less than that observed in un-saturated soil $(32$ species un-saturated versus 13 species saturated). Microbial community development within the saturated soil was characterized by a shift toward bacterial species of the phylum firmicutes and alpha- and delta-classes of the phylum proteobacteria (Fig. 4). The increase in Gram-positive firmicutes from 19\% (un-saturated) to $36 \%$ (saturated) corresponded with the PLFA biomarker analysis, i.e. increased $\%$ of a15:0. The observed shift in the proteobacteria from gamma, unsaturated, to alpha/delta, saturated, is likely reflected in the increased percentage of $18: 1 \omega 7 \mathrm{c}$ and cy19:0, both common in many proteobacteria (see Table 2 for a list of PLFA biomarkers detected in the saturated and unsaturated soils).

Terminal restriction fragments for Clostridia, Rhodococcus and Beijerinckia species were identified in the saturated soil and not in the unsaturated soil. All three genera of bacteria contain species known to utilize RDX as a sole source of carbon and/or nitrogen (personal communications, Drs. Neal Adrian and Herb Fredrickson, U.S. Army-ERDC; Bhushan et al., 2003; SethSmith et al., 2002). The emergence of other species of alpha-and delta-proteobacteria, i.e. Myxococcus, Methylosinus, Rhodobacter, and Sphingomonas were also unique to the saturated soil. Although these organisms have not been directly tied to nitramine biodegradation, the latter three genera have all been tied to the biodegradation of aromatic compounds. Certain Rhodobacter and Sphingomonas species facilitate ring cleavage via the protocatchuate enzyme whereas certain Methylosinus species can facilitate ring cleavage via a monooxygenase as well as oxidize a variety of aliphatic compounds (Buchan et al., 2001; Wattian et al., 2001; Green and Dalton, 1989). Within the saturated soil, the majority of organisms identified showed traits related to contaminant biodegradation if not specifically nitramine biodegradation. In addition, two other related species, Sporosarcina urea and Halobacillus halophilus, were identified as the most abundant, i.e. greatest TRF areas, bacteria present in the saturated soil. Both species can have the ability to synthesize urease and are widely distributed in surface soils. The ability to release ammonium ions might also have played a role in RDX loss through base induced catabolism (Heilmann et al., 1996).

Even though no species were identified that are known to degrade RDX in the unsaturated soil, some species were identified that have been observed to degrade other environmental pollutants. Burkholderia spp. have been isolated that show the ability to biodegrade 2,4-dinitrotoluene. Burkholderia was one of the more abundant species detected in our tests. Strains of the beta-proteobacteria Bordettella and the gammaproteobacteria Pseudomonas stutzeri are capable of degrading a variety of contaminants, including aromatic compounds (Eriksson et al., 2003; Spanggord et al., 1991). In short, the unsaturated soil fostered the development of a diverse community with biodegradative capabilities. However, an ideal soil moisture tension in terms of agricultural applications, i.e. 1/3 bar, is far less amenable to RDX biodegradation than is soil that is saturated.

In summary, we found that soil moisture tension had a significant effect on the development of indigenous microbes. Saturated soils fostered the development of a reduced environment that supported the complete biodegradation of the added RDX. The resulting, relatively simple, microbial community was enriched in firmicutes, and alpha- and delta proteobacteria. Specific bacterial genera known to degrade RDX were identified (i.e. Clostridium sp., Rhodococcus sp. and Beijerinckia sp.) as well as other genera with associated biodegradation capabilities

Table 2

PLFA biomarkers detected in Ft. Greely surface soils incubated under different soil moisture tensions

\begin{tabular}{|c|c|c|}
\hline \multicolumn{2}{|l|}{ Organisms } & \multirow{2}{*}{$\frac{\text { PLFA biomarkers }^{\mathrm{a}}}{\mathrm{n} 18: 2 \omega 6 \mathrm{c}, \mathrm{n} 20: 4 \omega 6 \mathrm{c}}$} \\
\hline Eukaryotes & $\omega 6$ series & \\
\hline & $\omega 3$ series & $\mathrm{n} 18: 3 \omega 3, \mathrm{n} 20: 5 \omega 3$ \\
\hline \multirow[t]{6}{*}{ Prokaryotes } & Gram-positive & i14:0, a15:0, i16:0, i17:0, a17:0 \\
\hline & Gram-negative & \\
\hline & Cyclopropyl & cy $17: 0$, cy $19: 0$ \\
\hline & $\omega 7$ series & $\mathrm{n} 16: 1 \omega 7 \mathrm{c}, \mathrm{n} 18: 1 \omega 7 \mathrm{c}$ \\
\hline & Other series & 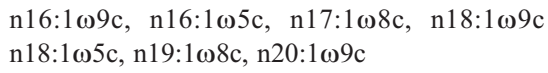 \\
\hline & Actinomycetes & 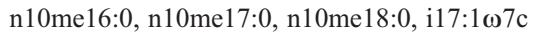 \\
\hline
\end{tabular}

a PLFA biomarkers are assigned to taxonomy according to Lechevalier and Lechevalier (1988), and Pinkart et al. (2002). 
(i.e. denitrification and ring cleavage). In addition, alkaline hydrolysis of the added RDX may have occurred. The unsaturated soils exhibited a significantly different endpoint microbial community and succession that was characterized by a considerably lower rate and extent of RDX biotransformation. The aerobic nature of the soil fostered the development of a diverse bacterial community with a capacity for contaminant biodegradation, if not one ideally suited to RDX biotransformation.

\section{Acknowledgements}

The authors would like to thank Drs. Tom Jenkins and Marianne Walsh and Mr. Larry Perry and Ms. Lauren Raymond. Without their technical assistance and insight, this work would not have been possible. This work was funded through the U.S. Army Engineer Research and Development Center, Environmental Laboratory, Basic Research Program Office administered by Dr. John Cullinane. This publication is by permission of the Chief of Engineers.

Dr. David C. White pioneered the development and use of membrane lipids in quantifying microbial communities in situ. This development has provided many researchers with a valuable tool for exploring microbes in a wide variety of environments. By applying this tool with care, insight into the movers and shakers of the microbial kingdom can be gained and this insight can and has been used to benefit us all. Thanks D.C.

\section{References}

American Academy of Microbiology, 2002. Microbial ecology and genomics: a crossroads of opportunity. A Report from the American Academy of Microbiology. ASM Press, Washington, D.C.

Baek, K.-H., Kim, H.-S., Moon, S.-H., Lee, I.-S., Oh, H.-M., Yoon, B.-D., 2004. Effects of soil types on the biodegradation of crude oil by Nocardia sp. H171. J. Microbiol. Biotechnol. 14, 901-905.

Balba, M.T., Al-Awadhi, N., Al-Daher, R., 1998. Bioremediation of oilcontaminated soil: microbiological methods for feasibility assessment and field evaluation. J. Microbiol. Methods 32, 155-164.

Balkwill, D.L., Leach, F.R., Wilson, J.T., McNabb, J.F., White, D.C., 1988. Equivalence of microbial biomass measures based on membrane lipid and cell wall components, adenosine triphosphate, and direct counts in subsurface sediments. Microb. Ecol. 16, 73-84.

Bhushan, B., Trott, S., Spain, J.C., Halasz, A., Paquet, L., Hawari, J., 2003. Biotransformation of hexahydro-1,3,5-trinitro-1,3,5-triazine (RDX) by a rabbit liver cytochrome P450: insight into the mechanism of RDX biodegradation by Rhodococcus sp. strain DN22. Appl. Environ. Microbiol. 69, 1347-1351.

Boopathy, R., Manning, J., Kulpa, C.F., 1998. Biotransformation of explosives by anaerobic consortia in liquid culture and in soil slurry. Int. Biodeterior. Biodegrad. 41, 67-74.

Buchan, A., Neidle, E.L., Moran, M.A., 2001. Diversity of the ring-cleaving dioxygenase gene pcaH in a salt marsh bacterial community. Appl. Environ. Microbiol. 67, 5801-5809.

Eriksson, M., Sodersten, E., Zhontang, Y., Dalhamma, G., Mohn, W.W., 2003. Degradation of polycyclic aromatic hydrocarbons at low temperature under aerobic and nitrate-reducing conditions in enrichment cultures from northern soils. Appl. Environ. Micobiol. 69, 275-284.

Federle, T.W., Dobbins, D.C., Thornton-Manning, J.R., Jones, D.D., 1986. Microbial biomass, activity, and community structure in subsurface soils. Ground Water 24, 365-374.

Green, J., Dalton, H., 1989. Substrate specificity of soluble methane monooxygenase: mechanistic implications. J. Biol. Chem. 264, 17,698-17,703.
Gruntzig, V., Stres, B., Ayala del Rio, H.L., Tiedje, J.M., 2002. Improved Protocol for T-RFLP by Capillary Electrophoresis. Center for Microbial Ecology, Michigan State Univ., East Lansing, MI. July. http://rdp.cme.msu. edu/html/t-rflp_jul02.html.

Guiot, S.R., Shen, C.F., Paquet, L., Breton, J., Hawari, J., 1999. Pilot-scale anaerobic bioslurry remediation of RDX and HMX contaminated soils. In: Alleman, B., Leeson, A. (Eds.), Bioremediation of Nitroaromatic and Haloaromatic Compounds, vol. 5. Battelle Press, Columbus, OH, pp. 15-18.

Heilmann, H.M., Wiesmann, U., Stenstrom, M.K., 1996. Kinetics of alkaline hydrolysis of high explosives RDX and HMX in aqueous solution and adsorbed to activated carbon. Environ. Sci. Technol. 30, 1485-1492.

Lechevalier, H., Lechevalier, M.P., 1988. Chemotaxonomic use of lipids — an overview. In: Ratledge, C., Wilkinson, S.G. (Eds.), Microbial Lipids, vol. 1. Academic Press, San Diego, California, pp. 869-902.

MacNaughton, S.J., Stephen, J.R., Venosa, A.D., Davis, G.A., Chang, Y.-J., White, D.C., 1999. Microbial population changes during bioremediation of an experimental oil spill. Appl. Environ. Microbiol. 65, 3566-3574.

Mancera-Lopez, M.E., Rodriquez-Casasola, M.T., Rios-Leal, E., EsparazaGarcia, F., Chavez-Gomez, B., Rodriguez-Vazquez, R., Barrera-Cortes, J., 2007. Fungi and bacteria isolated from two polluted soils for hydrocarbon degradation. Acta Chim. Slov. 54, 201-209.

Margesin, R., Labbe, D., Schinner, F., Greer, C.W., Whyte, L.G., 2003. Characterization of hydrocarbon-degrading microbial populations in contaminated and Pristine Alpine soils. Appl. Environ. Microbiol. 69, 3085-3092.

Margesin, R., Hämmerle, M., Tscherko, D., 2007. Microbial activity and community composition during bioremediation of diesel-oil-contaminated soil: effects of hydrocarbon concentration, fertilizers, and incubation time. Microb. Ecol. 53, 259-269.

McCormick, N.G., Cornell, J.H., Kaplan, A.M., 1981. Biodegradation of hexahydro-1,3,5-trinitro-1,3,5-triazine. Appl. Environ. Microbiol. 42, 817-823.

McIntyre, C.P., Harvey, P.M., Ferguson, S.H., Wressnig, A.M., Volk, H., George, S.C., Snape, I., 2007. Determining the extent of biodegradation of fuels using the diastereomers of acyclic isoprenoids. Environ. Sci. Technol. $41,2452-2458$.

Pinkart, H.C., Ringelberg, D.B., Piceno, Y.M., McNaughton, S.J., White, D.C., 2002. Biochemical approaches to biomass measurements and community structure analysis, In: Hurst, C.J., Crawford, R., Knudsen, G., McInerney, M.J., Stezenbach, L.D. (Eds.), Second edition. Manual of Environmental Microbiology. American Society for Microbiology Press, Washington, D.C., pp. 101-113.

Prichard, H.P., Costa, C.F., 1991. EPA’s Alaska oil spill bioremediation report. Environ. Sci. Technol. 25, 372-379.

Ringelberg, D.B., Talley, J.W., Perkins, E.J., Tucker, S.G., Luthy, R.G., Bower, E.J., Fredrickson, H.L., 2001. Succession of phenotypic, genotypic, and metabolic community characteristics during the in-vitro bioslurry treatment of PAH-contaminated sediments. Appl. Environ. Microbiol. 67 (4), $1542-1550$.

Ringelberg, D.B., Reynolds, C.M., Walsh, M.E., Jenkins, T.F., 2003. RDX loss in a surface soil under saturated and well drained conditions. J. Environ. Qual. 32, 1244-1249.

Seth-Smith, H.M.B., Rosser, S.J., Basran, A., Travis, E.R., Dabbs, E.R., Nicklin, S., Bruce, N.C., 2002. Cloning, sequencing, and characterization of the hexahydro-1,3,5-trinitro-1,3,5-triazine degradation gene cluster from Rhodococcus rhodochrous. Appl. Environ. Microbiol. 68, 4764-4771.

Sikkema, J., de Bont, J.A.M., Poolman, B., 1995. Mechanisms of membrane toxicity of hydrocarbons. Microbiol. Rev. 59, 201-222.

Smith, G.A., Nickels, J.S., Kerger, B.D., Davis, J.D., Collins, S.P., 1986. Quantitative characterization of microbial biomass and community structure in subsurface material: a prokaryotic consortium responsive to organic contamination. Can. J. Microbiol. 32, 104-111.

Spanggord, R.J., Spain, J.C., Nishino, S.F., Mortlemans, K.E., 1991. Biodegradation of 2,4-dinitrotoluene by a Pseudomonas sp. Appl. Environ. Microbiol. 57, 3200-3205.

Speitel, G.E., Engels, T.L., McKinney, D.C., 2001. Biodegradation of RDX in unsaturated soil. Biorem. J. 5, 1-11.

Talley, J.W., Zhang, X., Waisner, S., Ringelberg, D., Hansen, L., 2004. Study of the potential for bioremediation of petroleum hydrocarbons within smear zone soils. J. Environ. Eng. 130, 1401-1406. 
Wattian, P., Bastiaens, L., van Herwijnen, R., Paal, L., Parsons, J.R., Renard, M.E., Springael, D., Cornelis, G.R., 2001. Fluorene degradation by Sphingomonas sp. LB126 proceeds through protocatchuate acid: A genetic analysis. Res. Microbiol. 152, 861-872.

White, D.C., Ringelberg, D.B., 1998. Signature lipid biomarker analysis. In: Burlage, R.S., Atlas, R., Stahl, D., Geesey, G., Sayler, G. (Eds.), Techniques in Microbial Ecology. Oxford University Press, Inc., New York, pp. 255-272.

White, D.C., Flemming, C.A., Leung, K.T., Macnaughton, S.J., 1998. In situ microbial ecology for quantitative assessment, monitoring and risk assessment of pollution remediation in soils, the subsurface, the rhizosphere and in biofilms. J. Microbiol. Methods 32, 93-105.

Zhao, J.S., Greer, C.W., Thiboutot, S., Ampleman, G., Hawari, J., 2004. Biodegradation of the nitramine explosives hexahydro-1,3,5-trinitro-1,3,5triazine and octahydro-1,3,5,7-tetranitro-1,3,5,7-tetrazocine in cold marine sediment under anaerobic and oligotrophic conditions. Can. J. Microbiol. 50, 91-96. 